\title{
Edukasi Promosi Kesehatan dan Pemberdayaan Masyarakat pada Masa Pandemi Covid-19
}

\author{
Sufiyanto $^{1^{*}}$, Sari Yuniarti ${ }^{2}$ dan R Djoko Andrijono ${ }^{3}$ \\ ${ }^{1,3}$ Teknik Mesin Univ. Merdeka Malang, Jl. Terusan Raya Dieng No. 62-64, Malang, Indonesia, 65146 \\ ${ }^{2}$ D3 Perbankan Univ. Merdeka Malang, Jl. Terusan Raya Dieng No. 62-64, Malang, Indonesia, 65146
}

Correspondence: Sufiyanto (sufiyanto@unmer.ac.id)

Received: 30 Juni 2021 - Revised: 01 Agustus 2021 - Accepted: 16 Agustus 2021

\begin{abstract}
Abstrak. Penerapan protokol kesehatan di masyarakat pada masa pandemi Covid-19 saat ini masih terkendala dan belum efektif. Rendahnya tingkat kesadaran dan pemahaman masyarakat dalam penerapan protokol kesehatan merupakan faktor utamanya. Masyarakat belum sepenuhnya menerima dan menerapkan aturan protokol kesehatan sebagai bentuk budaya baru yang harus diterapkan dalam tatanan New Normal. Dampak terpuruknya sektor ekonomi juga merupakan faktor yang memperburuk kondisi perekonomian masyarakat utamanya industri kecil dan UMKM. Tujuan kegiatan pengabdian ini untuk meningkatkan kesadaran masyarakat dalam penerapan protokol kesehatan dan pemberdayaan bagi UMKM pada masa pandemi Covid-19. Metode pelaksanaan kegiatan pengabdian ini adalah: 1). membuat video tutorial sebagai sarana sosialisasi dan edukasi promosi kesehatan, 2). Membuat video company profile untuk membantu promosi industri kecil dan UMKM. Penyebarluasan video tutorial dan company profile UMKM melalui media sosial Youtube merupakan cara yang efektif dalam penyampaian informasi di dalamnya. Konten yang menarik dan interaktif yang mudah dipahami menjadi kunci keberhasilan penyebaran informasi melalui media sosial. Selain itu ketertarikan masyarakat utamanya generasi milenial dalam mengakses informasi di media sosial menjadi faktor pendukung keberhasilan penyampaian informasi tersebut.
\end{abstract}

Kata kunci: Promosi Kesehatan, Video Tutorial, Pemberdayaan UMKM, Video Company Profile

Citation Format: Sufiyanto, Yuniarti, S \& Andrijono, R.D. (2021). Edukasi Promosi Kesehatan Dan Pemberdayaan Masyarakat Pada Masa Pandemi Covid-19. Prosiding Seminar Nasional Abdimas Ma Chung (SENAM), 01-14. 


\section{PENDAHULUAN}

Wabah Covid-19 yang muncul di awal 2020 telah berubah menjadi sebuah pandemi dan menjadi ancaman yang serius bagi semua negara di belahan dunia ini. Dampak luas pandemi Covid-19 mengakibatkan kondisi krisis di segala sektor kehidupan masyarakat dan negara. Tingginya tingkat penularan dan penyebaran virus Covid-19 yang berisiko kematian menyebabkan semua negara menerapkan kebijakan lock down di negaranya. Aktivitas manusia di segala sektor sangat dibatasi dengan kebijakan tersebut. Arus perdagangan antar negara, benua, pulau, provinsi dan kota menjadi lumpuh sebagai konsekuensi kebijakan lock down. Krisis ekonomi akibat lumpuhnya industri dan perdagangan sebagai dampak meluasnya pandemi Covid-19 yang harus dihadapi oleh sebagian besar negara (Berawi, 2020; Irawan, dkk. 2020).

Pemerintah Indonesia di awal 2020 menerapkan kebijakan Pembatasan Sosial Berskala Besar (PSBB) (Yunus, dkk., 2020) (WHO, 2020) sebagai upaya mengantisipasi dampak penularan dan penyebaran virus Covid-19. Kebijakan PSBB ini diterapkan pemerintah sampai bulan Juni 2020. Penerapan kebijakan PSBB tersebut mengakibatkan tekanan ekonomi yang sangat besar secara nasional. Penurunan produktivitas, penjualan produk dan jasa sebagai akibat kebijakan PSBB berdampak pada tingginya tingkat Pemutusan Hubungan Kerja (PHK) di sektor industri dan perdagangan. Banyak perusahaan dan industri tidak mampu membayar gaji karyawannya selama penerapan kebijakan tersebut. Penurunan daya beli masyarakat akibat tingginya PHK melemahkan sektor ekonomi yang berkembang menjadi krisis berdampak pada semua sendi kehidupan masyarakat.

Pemerintah mulai melonggarkan kebijakan PSBB karena tekanan ekonomi secara nasional semakin meningkat. Melalui penerapan kebijakan PSBB yang ketat, pemerintah berharap dapat menekan tingkat penularan dan kematian akibat virus Covid-19. Di sisi lain, kebijakan tersebut berdampak pada tekanan ekonomi yang kuat secara nasional. Sebagai langkah antisipasi dalam pelonggaran kebijakan PSBB, pemerintah menerapkan aturan atau tatanan baru sebagai bentuk adaptasi terhadap situasi pandemi Covid-19. Tatanan New Normal dengan penerapan protokol kesehatan (KMK No. HK.01.07MENKES-413-2020) merupakan aturan yang harus diimplementasikan dalam kehidupan normal masyarakat pada masa pandemi Covid-19 (Satria, dkk., 2020). Penerapan protokol kesehatan ini merupakan langkah proteksi diri masyarakat dalam menjalani kehidupan 
normal (Irawan, dkk., 2020; Prayitno dkk., 2020) untuk mencegah penularan dan penyebaran virus Covid-19 serta diharapkan dapat menekan risiko kematian akibat virus Covid-19 (Majid, 2020) (WHO, 2020).

Setelah penerapan tatanan New Normal di masyarakat, fakta angka penularan dan kematian akibat virus Covid-19 tetap bertambah. Kasus penularan dan kematian akibat virus Covid-19 kembali meningkat di akhir tahun 2020. Pemerintah kembali menerapkan kebijakan Pemberlakuan Pembatasan Kegiatan Masyarakat (PPKM) di awal tahun 2021 yang kemudian berlanjut dengan PPKM Mikro untuk 7 provinsi yaitu: Banten, DKI Jakarta, Jawa Barat, Jawa Tengah, DIY, Jawa Timur, dan Bali.

Beberapa ketentuan protokol kesehatan dalam aturan New Normal antara lain: penerapan pola hidup sehat (PHBS), penggunaan alat pelindung diri, dan pembatasan interaksi fisik (WHO, 2020). Dalam praktiknya, penerapan protokol kesehatan di masyarakat masih terkendala dan belum efektif. Faktor utama yang menjadi penghambat adalah rendahnya tingkat kesadaran dan pemahaman masyarakat dalam penerapan protokol kesehatan. Masyarakat belum sepenuhnya menerima dan menerapkan aturan protokol kesehatan sebagai bentuk budaya baru yang harus diterapkan dalam tatanan New Normal.

Pemerintah berupaya melakukan langkah sosialisasi dan edukasi untuk meningkatkan kesadaran dan pemahaman masyarakat dalam penerapan protokol kesehatan (Zahrotunnimah, 2020) (Caesaron, dkk., 2021). Salah satu program sosialisasi dan edukasi yang dilakukan pemerintah adalah penilaian mandiri terhadap risiko penularan Covid-19 (https://covid19.go.id) melalui aplikasi Inarisk Personal yang dikembangkan oleh Badan Nasional Penanggulangan Bencana (BNPB) (Sufiyanto, dkk., 2020) (BNPB, 2020). Namun program tersebut masih belum mempunyai dampak yang signifikan dalam meningkatkan kesadaran masyarakat. Untuk itu tetap diperlukan upaya lain dalam melakukan sosialisasi dan edukasi guna meningkatkan kesadaran dan pemahaman masyarakat tentang penerapan protokol kesehatan (Sufiyanto, dkk., 2020).

Media sosial telah menjadi bagian penting dalam kehidupan masyarakat di era digital ini (Widayati, dkk., 2021). Masyarakat utamanya generasi milenial telah terbiasa dengan komunikasi dan informasi melalui media sosial. Dengan media sosial, penyebaran informasi menjadi lebih luas dan lebih cepat penyampaiannya. Untuk itu, sosialisasi dan edukasi tentang protokol kesehatan melalui media sosial perlu dilakukan (Audry dkk., 
2020; Sampurno dkk., 2020). Konten yang menarik dan interaktif yang mudah dipahami menjadi kunci keberhasilan penyebaran informasi melalui media sosial.

Protokol kesehatan yang paling efektif diterapkan oleh masyarakat dalam kehidupan sehari-hari adalah penggunaan masker, face shield, dan hand sanitizer. Ketiga alat tersebut merupakan perlengkapan untuk melindungi diri dari penyebaran dan penularan virus Covid-19 (Choiriyah, dkk., 2021). Kebutuhan ketiga perlengkapan ini akan berlangsung secara terus menerus karena penerapan protokol kesehatan telah menjadi bagian budaya dalam kehidupan New Normal ini. Kemandirian masyarakat dalam penyediaan ketiga perlengkapan tersebut menjadi hal penting agar selalu tersedia setiap saat dan dapat diperoleh kapan saja dengan harga murah (Kusumaningrum, dkk., 2021). Untuk itu, edukasi atau tutorial yang berisi cara membuat ketiga perlengkapan tersebut perlu diberikan kepada masyarakat agar mampu menyediakan atau membuatnya secara mandiri dari bahan yang ada di sekitarnya. Selain itu, juga mengenalkan alternatif bahan yang bersifat alamiah atau herbal dalam pembuatan hand sanitizer yang lebih aman dan ramah lingkungan.

Selain edukasi dan sosialisasi tentang protokol kesehatan, upaya pemberdayaan ekonomi masyarakat yang memiliki Usaha Mikro, Kecil, dan Menengah (UMKM) juga perlu dilakukan. Untuk menggerakkan ekonomi khususnya UMKM di masa pandemi Covid-19, maka diperlukan upaya untuk membantu promosi melalui pembuatan profil usaha yang diunggah ke media sosial. Profil usaha UMKM yang menarik diharapkan dapat menjadi media promosi usaha agar lebih dikenal secara luas oleh masyarakat. Pengenalan produk dan informasi lokasi dalam profil usaha menjadi informasi yang penting dalam promosi usaha dan pemberdayaan masyarakat pemilik UMKM.

\section{MASALAH}

Berdasarkan analisis situasi yang telah diuraikan di atas, maka permasalahan yang dihadapi oleh masyarakat pada masa pandemi Covid-19 adalah:

1. Masih rendahnya tingkat kesadaran dan pemahaman masyarakat dalam penerapan protokol kesehatan di era New Normal.

2. Perlunya pemberdayaan UMKM akibat dampak ekonomi yang terpuruk pada masa pandemi Covid-19. 


\section{METODE PELAKSANAAN}

Kegiatan pengabdian masyarakat ini dilakukan dengan cara membuat video tutorial sebagai upaya edukasi promosi kesehatan kepada masyarakat dan video profil usaha sebagai upaya promosi UMKM. Penyebaran video tutorial promosi kesehatan dan video profil usaha UMKM ini dilakukan melalui sharing di media sosial di Youtube, Instagram dan Facebook. Sharing kedua produk pengabdian di media sosial dilakukan untuk memudahkan penyebaran informasi dan metode yang banyak dilakukan dalam masa pandemi Covid-19 saat ini.

\section{Skedul Pelaksanaan Kegiatan}

Kegiatan pengabdian masyarakat ini dilaksanakan selama 3 minggu mulai 18 Januari s/d 8 Februari 2021. Kegiatan ini melibatkan 20 mahasiswa yang terbagi dalam 2 (dua) tim yaitu: tim edukasi promosi kesehatan dan tim pemberdayaan UMKM. Adapun skedul pelaksanaan kegiatan pengabdian ini dapat dilihat pada Tabel 1.

Tabel 1. Skedul pelaksanaan kegiatan

\begin{tabular}{|c|c|c|c|c|c|c|c|c|c|c|c|c|c|c|c|c|c|c|c|c|c|c|}
\hline \multirow{3}{*}{ No } & \multirow{3}{*}{ Kegiatan } & \multicolumn{21}{|c|}{ Alokasi Waktu } \\
\hline & & \multicolumn{7}{|c|}{ Minggu Ke-1 } & \multicolumn{7}{|c|}{ Minggu Ke-2 } & \multicolumn{7}{|c|}{ Minggu Ke-3 } \\
\hline & & 1 & 2 & 3 & 4 & 5 & 6 & 7 & 1 & 2 & 3 & 4 & 5 & 6 & 7 & 1 & 2 & 3 & 4 & 5 & 6 & 7 \\
\hline \multicolumn{23}{|c|}{ Persiapan Program } \\
\hline 1. & Penyusunan skedul dan tahapan kegiatan & & & & & & & & & & & & & & & & & & & & & \\
\hline 2. & Proses pembuatan storyline dan script & & & & & & & & & & & & & & & & & & & & & \\
\hline 3. & Membeli peralatan dan bahan yang dibutuhkan & & & & & & & & & & & & & & & & & & & & & \\
\hline 4. & Survey UMKM & & & & & & & & & & & & & & & & & & & & & \\
\hline \multicolumn{23}{|c|}{ Pelaksanaan Program } \\
\hline 1. & Pembuatan content video & & & & & & & & & & & & & & & & & & & & & \\
\hline 2. & Penyusunan konsep editing video & & & & & & & & & & & & & & & & & & & & & \\
\hline 4. & Pengeditan content video & & & & & & & & & & & & & & & & & & & & & \\
\hline \multicolumn{23}{|c|}{ Evaluasi Program } \\
\hline 1. & Pembuatan dokumentasi kegiatan & & & & & & & & & & & & & & & & & & & & & \\
\hline 2. & Upload video tutorial dan video profil UMKM & & & & & & & & & & & & & & & & & & & & & \\
\hline 3. & Penyusunan laporan kegiatan & & & & & & & & & & & & & & & & & & & & & \\
\hline
\end{tabular}

\section{Uraian Tahapan Kegiatan}

Tahapan kegiatan secara garis besar terdiri dari 3 tahap, yaitu: persiapan, pelaksanaan, dan evaluasi program. Adapun uraian masing-masing tahap sebagai berikut:

\section{Tahap persiapan}

Tim pelaksana mengawali kegiatan dengan koordinasi untuk menyusun skedul dan tahapan kegiatan sesuai dengan tim kerja yang sudah ditetapkan yaitu tim promosi 
kesehatan dan tim pemberdayaan UMKM. Masing-masing tim bertugas mengidentifikasi data dan kebutuhan yang diperlukan dalam pelaksanaan program. Tim promosi kesehatan menginventaris kebutuhan data dan bahan yang diperlukan dalam membuat program promosi kesehatan. Sedangkan tim pemberdayaan UMKM mengidentifikasi kebutuhan data dan pemetaan UMKM di sekitar kampus.

Setelah itu, kedua tim mengikuti bimbingan teknis dari LPPM Universitas Merdeka Malang dalam pembuatan storyline dan script yang diperlukan dalam membuat layout atau kerangka video. Kemudian, kedua tim menyusun konsep storyline dan script sesuai dengan tema program yang dibuat.

\section{Tahap pelaksanaan}

Mengacu pada konsep storyline dan script yang sudah dibuat pada tahap persiapan, tim melanjutkan untuk membuat konten video. Konten video berisi rekaman-rekaman pendek yang diambil berdasarkan acuan storyline dan script. Rekaman video pendek tersebut nantikan akan digabungkan dan diedit untuk menghasilkan produk video yang sesuai dengan tujuan program.

Sebelum masuk ke proses editing, kedua tim mengikuti bimbingan teknis kedua dengan materi editing dan finishing video. Selanjutnya tim membuat konsep editing yang diperlukan untuk membuat struktur atau susunan konten video sesuai dengan storyline. Struktur video yang dibuat terdiri dari: bumper opening, perkenalan, isi tutorial atau profil usaha, dan bumper closing. Setelah itu, masing-masing tim melanjutkan proses editing dan finishing produk video tutorial dan video profil usaha. Acuan proses editing yang ditentukan adalah durasi video berdurasi 3 sampai 5 menit.

\section{Tahap evaluasi}

Pada tahap ini, masing-masing tim melengkapi beberapa dokumentasi kegiatan yang terkait selama pelaksanaan program. Dokumentasi ini menjadi bagian informasi tambahan yang ditampilkan dalam deskripsi pada masing-masing produk video yang akan diunggah di media sosial. Untuk video tutorial, informasi tersebut berupa: bahanbahan yang diperlukan, komposisi atau spesifikasi produk, dan tahapan proses pembuatan. Sedangkan untuk video profil usaha UMKM, informasi yang ditampilkan berupa: nama UMKM, alamat atau peta lokasi, macam produk dan harga. Setelah produk video selesai, selanjutnya tim pelaksana kegiatan pengabdian mengunggah karya produk video tutorial dan video profil usaha ke media sosial. Hal ini dilakukan 
sebagai bentuk promosi digital untuk menyebarluaskan informasi kepada masyarakat luas. Selain itu promosi digital melalui media sosial merupakan salah satu cara yang efektif dan banyak dilakukan pada masa pandemi Covid-19 saat ini

\section{HASIL DAN PEMBAHASAN}

\section{Program Kegiatan}

Kegiatan pengabdian yang dilakukan terdiri dari 2 kelompok program, yaitu: promosi kesehatan dan pemberdayaan UMKM. Program promosi kesehatan ini bertujuan untuk memberikan edukasi kepada masyarakat terkait penerapan protokol kesehatan dalam tatanan kehidupan New Normal. Beberapa materi yang terkait dengan edukasi promosi kesehatan adalah:

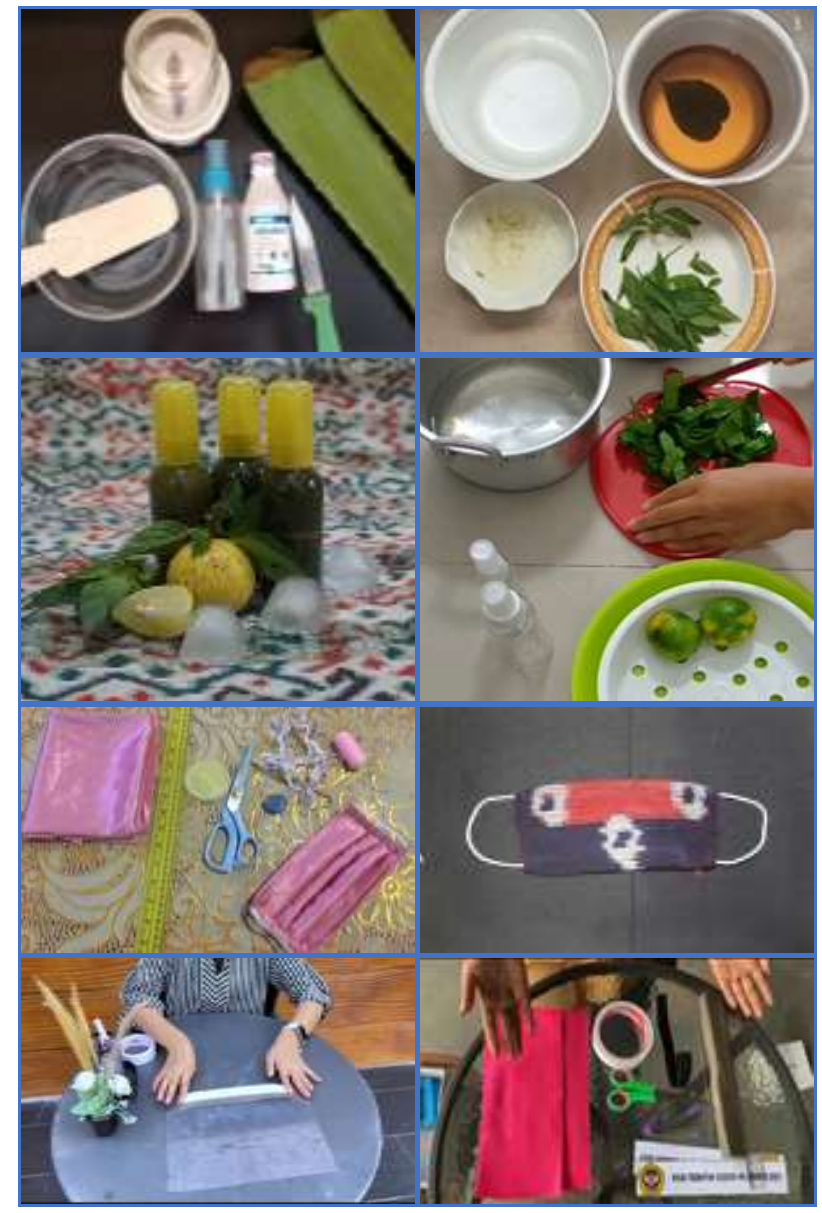

Gambar 1. Produk edukasi promosi Kesehatan

1. Pembuatan hand sanitizer secara mandiri dan menggunakan bahan alami atau herbal yang banyak tersedia di sekitar masyarakat, antara lain: daun sereh, daun sirih, jeruk nipis, lidah buaya dan daun kemangi 
2. Pembuatan masker berbahan kain yang mudah dan murah

3. Pembuatan face shield yang praktis, murah dan aman

Program pemberdayaan UMKM dilakukan untuk mempromosikan UMKM. Kategori UMKM tersebut adalah sejenis industri kecil atau home industry. Company profil yg dibuat dalam program pemberdayaan ini bertujuan untuk mengenalkan dan mempromosikan UMKM tersebut. UMKM yang dipilih adalah usaha kecil yang menghasilkan produk-produk khas daerah atau tradisional. Beberapa UMKM yang dibantu promosinya dalam program pemberdayaan ini, antara lain:

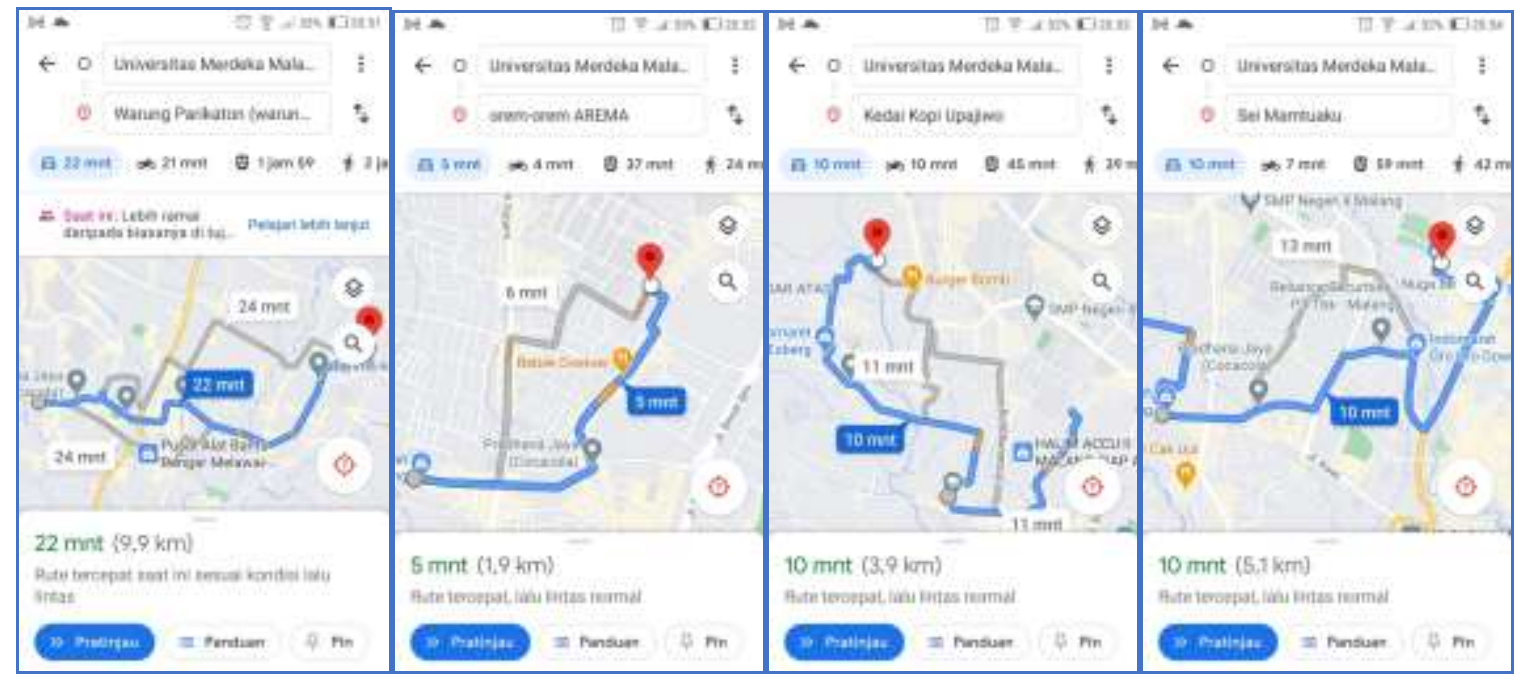

Gambar 2. Lokasi map UMKM

1. Warung Parikaton, alamat: Jl. Wijaya Kusuma Sekaran, Sekarpuro, Kec. Pakis, Malang, Jawa Timur - Kontak WA: 082141728667. Produk yang ditawarkan adalah beberapa menu makanan dan minuman tradisional yang disajikan dengan nuansa alami pedesaan

2. Orem-orem Arema, alamat: Jl. Blitar no 14a, Sumbersari, Kec. Lowokwaru, Kota Malang, Jawa Timur, Kontak WA: 0816557443. Produk yang ditawarkan adalah menu makanan tradisional khas Jawa Timur yaitu orem-orem.

3. Kedai Kopi Upajiwo, alamat: Jl. Raya Candi V1 No. 6 Dinoyo, Kec. Lowokwaru, Kota Malang Jawa Timur, Kontak WA: 082251571852. Kedai ini menawarkan menu macam-macam minuman kopi dan minuman tradisional wedang uwuh.

4. Se'i Sapi Mamtua, alamat: Jl. Tawangmangu No. 21 Kav. 4, Kota Malang Jawa Timur, Kontak WA: 081233604409. Warung makan ini menawarkan produk beberapa menu makanan khas daging asap dari NTT. 


\section{Tahapan Pembuatan Video Tutorial dan Video Company Profile}

Sebelum proses pembuatan video, masing-masing tim pelaksana program membuat storyline dan script sebagai acuan dalam pembuatan isi (content) dan struktur video. Hal ini penting dilakukan agar materi edukasi dan promosi yang disampaikan dapat efektif serta untuk mengatur durasi videonya. Berikut salah satu bentuk storyline untuk video tutorial dan video company profile UMKM.

Tabel 2. Storyline untuk video tutorial promosi Kesehatan

\begin{tabular}{|c|c|c|c|c|}
\hline NO & SKENARIO & SCRIPT VIDEO & SCRIPT AUDIO & DURASI \\
\hline 1. & $\begin{array}{l}\text { Opening Scene } \\
\text { - Logo UNMER MALANG } \\
\text { - Logo LPPM }\end{array}$ & $\begin{array}{l}\text { - Logo UNMER berputar } 360^{\circ} \\
\text { - Logo LPPM stil to outframe }\end{array}$ & $\begin{array}{l}\text { - VO : "UNIVERSITAS MERDEKA MALANG } \\
\text { MEMPERSEMBAHKAN KKN TEMATIK 2021" } \\
\text { - BS : Music Slow }\end{array}$ & $15^{\prime \prime}$ \\
\hline 2. & - Perkenalan Reporter & $\begin{array}{l}\text { - Mahasiswa sebagai reporter berdiri } \\
\text { dengan latar belakang polos }\end{array}$ & $\begin{array}{l}\text { - Dialog Reporter : “Assalamualaikum WR WB, hai } \\
\text { teman-teman semua perkenalkan nama mahasiswa } \\
\text { Yanuarius Sarbunan, selanjutnya..................." } \\
\text { - BS : Music Slow }\end{array}$ & $17 "$ \\
\hline 3. & $\begin{array}{l}\text { Main Body } \\
\text { - Peroses pembuatan }\end{array}$ & $\begin{array}{l}\text { - Mahasiswa memperaktekan cara } \\
\text { pembuatan }\end{array}$ & $\begin{array}{l}\text { - Dialog: "Langkah step pertama temen-temen bisa ambil } \\
\text { daun kemangi, kemudian temen-temen cincang, cincang } \\
\text { kasar aja..............selanjutnya" } \\
\text { - BS : Musik Slow }\end{array}$ & $221 "$ \\
\hline 5. & $\begin{array}{l}\text { Closing } \\
\text { - Kesimpulan }\end{array}$ & $\begin{array}{l}\text { - Mahasiswa sebagai reporter berdiri } \\
\text { dengan latar belakang polos }\end{array}$ & $\begin{array}{l}\text { - Dialog: "Oke teman-teman begitulah tadi cara } \\
\text { pembuatan handsanitizer...................selanjutnya" } \\
\text { - BS : Musik Slow }\end{array}$ & $15^{\prime \prime}$ \\
\hline 6. & $\begin{array}{l}\text { - Logo UNMER MALANG } \\
\text { - Logo LPPM }\end{array}$ & $\begin{array}{l}\text { - Logo UNMER berputar } 360^{\circ} \\
\text { - Logo LPPM stil to outframe }\end{array}$ & - BS : Musik Slow & $8 "$ \\
\hline
\end{tabular}

Tabel 3. Storyline untuk video company profile UMKM

\begin{tabular}{|c|c|c|c|c|}
\hline NO & SKENARIO & SCRIPT VIDIO & SCRIPT AUDIO & DURASI \\
\hline 1 & $\begin{array}{l}\text { Opening scane } \\
\text { - Logo UNMER MALANG } \\
\text { - Foto bersama pemilik } \\
\text { usaha } \\
\text { - Foto rumah makan }\end{array}$ & - Logo unmer malang berputar $360^{\circ}$ & $\begin{array}{l}\text { - VO:" Universitas merdeka malang malang } \\
\text { mempersembahkan KKN tematik" } \\
\text { " Bs : music slow }\end{array}$ & $15 "$ \\
\hline 2 & - Perkenalan reporter & $\begin{array}{l}\text { - Mahasiswa sebagai reporter foto } \\
\text { bersama pemilik UMKM } \\
\text { - Membuat vidio keseluruhan rumah } \\
\text { makan orem-orem arema }\end{array}$ & $\begin{array}{l}\text { - Dialog reporter (Dubbing) “ hallo teman-teman } \\
\text { perkenalkan saya christine, sekarang sya berada di } \\
\text { rumah makan orem-orem arema malang yang terkenal } \\
\text { dengan rasanya yang khas........." } \\
\text { - BS: music slow }\end{array}$ & $25^{\prime \prime}$ \\
\hline 3 & - Pengenalan usaha & $\begin{array}{l}\text { - Pembuatan vidio Penjelasan usaha } \\
\text { oleh pemilik usaha UMKM }\end{array}$ & $\begin{array}{l}\text { - Vo: pengenalan usaha oleh pemilik UMKM } \\
\text { Bs : music slow }\end{array}$ & $130^{\prime \prime}$ \\
\hline 4 & $\begin{array}{l}\text { Closing } \\
\text { - Kesimpulan }\end{array}$ & $\begin{array}{l}\text { - Reporter duduk sambil menikmati } \\
\text { makanan }\end{array}$ & $\begin{array}{l}\text { - Dialog (Dubbing) } \\
\text { "nah , dari vidio dan penjelasan sebelumnya teman- } \\
\text { teman sudah bisa melihat betapa enak dan lezatnya } \\
\text { makanan khas orem-orem arema ini, jadi tunggu apa } \\
\text { lagi buruan kesini dan menikamati makanan ini" } \\
\text { - Bs : music slow }\end{array}$ & $100 "$ \\
\hline 5 & $\begin{array}{l}\text { - Logo unmer malang } \\
\text { - Foto UMKM }\end{array}$ & - Logo UNMER MALANG & - Bs : muic slow & $15 "$ \\
\hline
\end{tabular}

Untuk keseragaman struktur video yang dibuat oleh setiap tim, maka ditetapkan format sebagai berikut:

1. Sesuai dengan storyline dan script yang sudah disetujui

2. Durasi video antara $3 \mathrm{~s} / \mathrm{d} 5$ menit 
3. Struktur layout video :

a. Opening bumper (official Unmer-LPPM-KKN Tematik)

b. Identitas mahasiswa

c. Isi video tutorial/profil usaha

d. Closing bumper (official Unmer-LPPM-KKN Tematik)

Adapun tampilan opening dan closing bumper sebagai berikut:

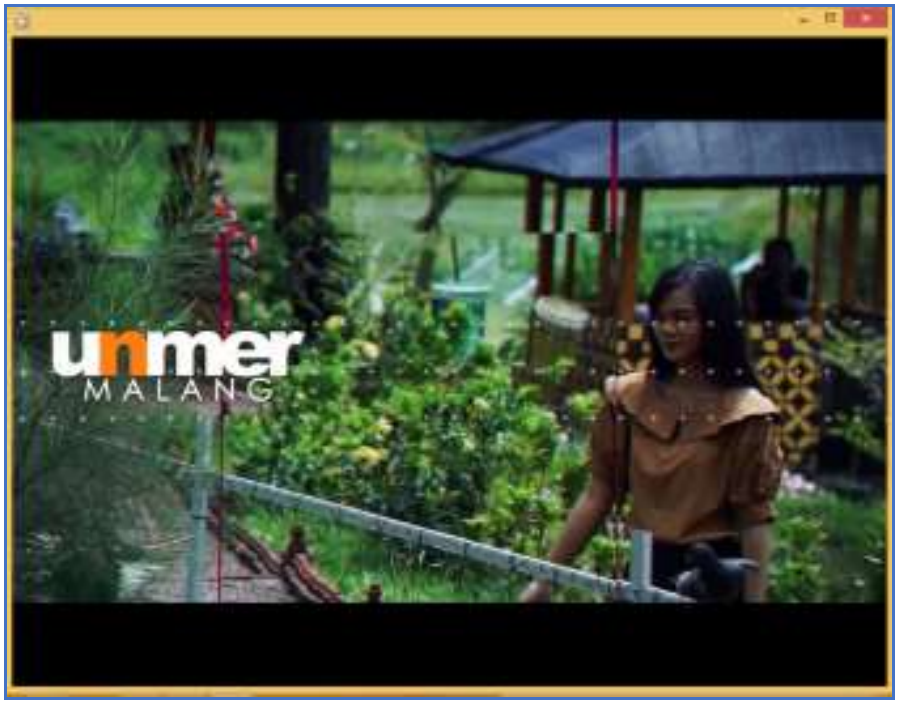

Gambar 3. Opening bumper video

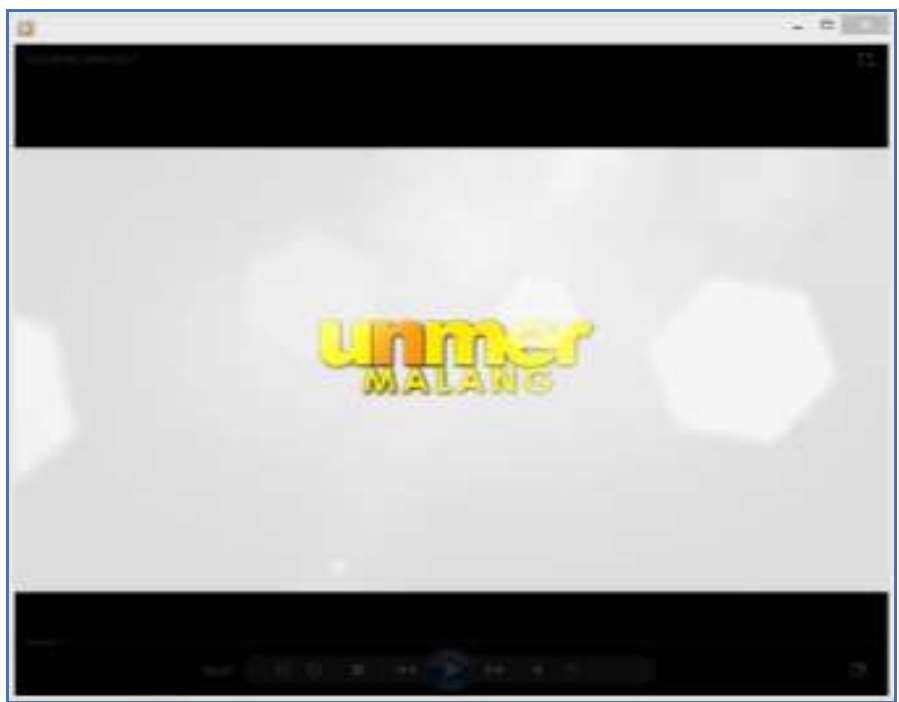

Gambar 4. Closing bumper video

\section{Hasil Produk Video}

Proses editing dan finishing dilakukan agar durasi video sesuai dengan ketentuan yang direncanakan dan sesuai dengan struktur format video yang ditetapkan. Selain itu, 
dalam proses editing juga dilakukan penambahan informasi dalam bentuk teks untuk memperjelas materi edukasi dan promosi yang bersifat penting serta mudah diingat. Berikut beberapa tampilan (screen shoot) hasil produk video tutorial dan video company profile UMKM. Pada gambar 5 terdapat 4 video company profile UMKM yaitu: 1). Warung Parikatorn; 2). Orem-Orem Arema; 3). Kedai Kopi Upojiwo; 4). Se'i Sapi Mamtua. Untuk program edukasi promosi kesehatan (gambar 6) ada video tutorial pembuatan: 1). hand sanitizer dari bahan alami dan herbal; 2). masker kain dari bahan yang murah dan aman.

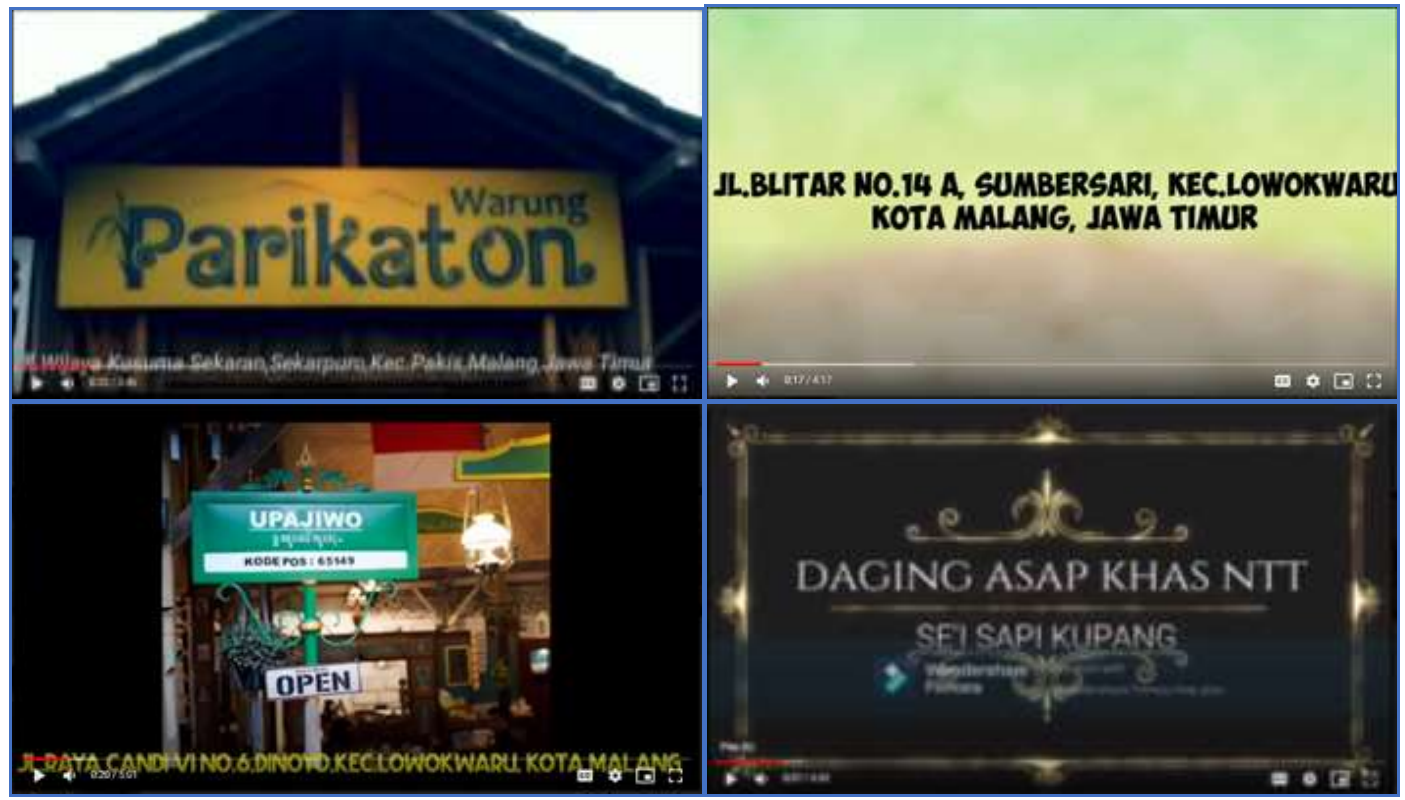

Gambar 5. Produk video profil UMKM

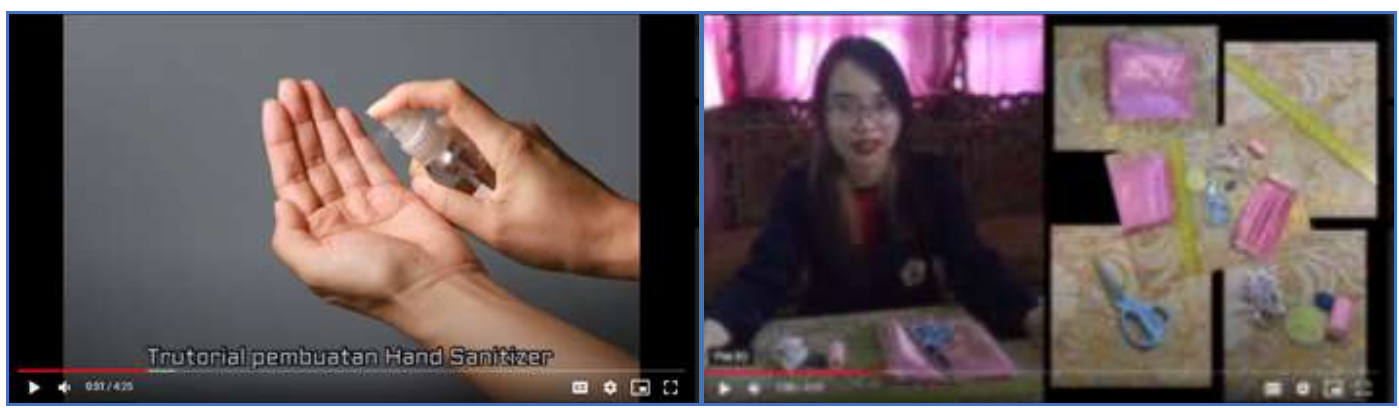

Gambar 6. Produk video program promosi kesehatan

\section{Promosi Digital}

Untuk memberikan edukasi dan promosi UMKM secara luas kepada masyarakat, produk video tutorial dan video company profil di-share melalui media youtube di LPPM Unmer Channel. LPPM Unmer Channel adalah media youtube yang digunakan untuk menyebarluaskan hasil-hasil kegiatan penelitian dan pengabdian masyarakat yang 
dihasilkan oleh Civitas Akademika Universitas Merdeka Malang. Berikut tampilan media youtube di LPPM Unmer Channel (gambar 7).

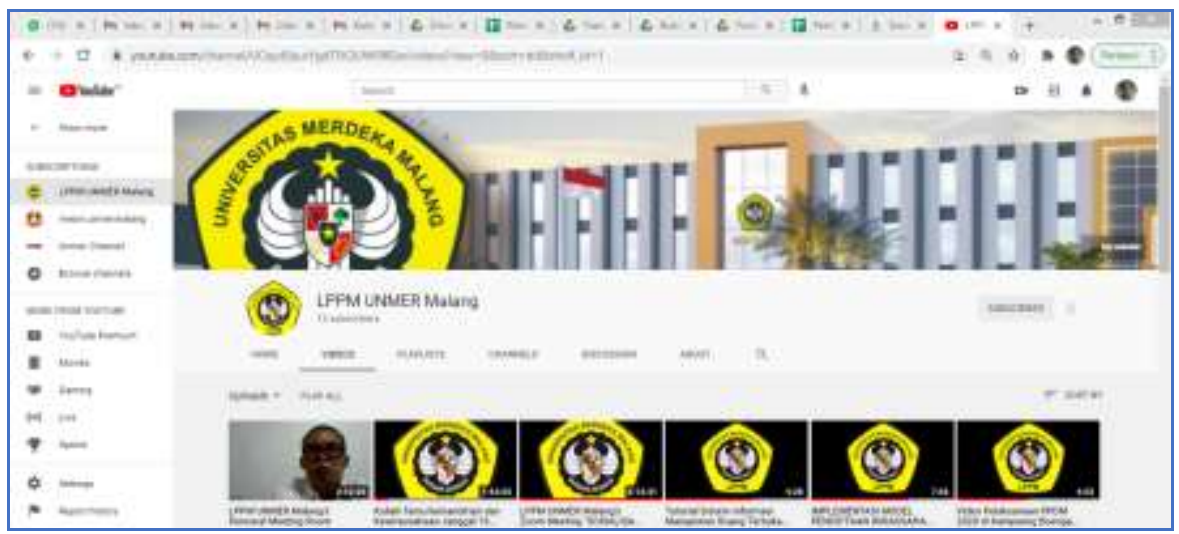

Gambar 7. Media youtube LPPM Unmer Channel.

\section{KESIMPULAN}

Kegiatan yang bertema "Edukasi Protokol Kesehatan dan Pemberdayaan Masyarakat Pada Masa Pandemi Covid-19” sebagai bentuk pengabdian kepada masyarakat yang dilakukan oleh Civitas Akademika Universitas Merdeka Malang. Dari hasil kegiatan kegiatan pengabdian ini sangat membantu program pemerintah dalam upaya memutus mata rantai penyebaran dan penularan Covid-19. Melalui video tutorial promosi kesehatan dapat menjadi media edukasi kepada masyarakat untuk meningkatkan kesadaran masyarakat dalam penerapan protokol kesehatan di masa pandemi Covid-19. Selain itu, video tutorial ini juga dapat membantu memberikan wawasan dan inovasi baru kepada masyarakat untuk membuat ide usaha baru membuat produk-produk seperti hand sanitizer, masker, dan face shield sebagai upaya untuk mengembalikan perekonomian masyarakat. Untuk program pemberdayaan ekonomi UMKM dapat membantu meningkatkan promosi usaha UMKM yang terdampak akibat pandemi Covid-19. Video company profile UMKM yang dihasilkan dalam kegiatan pengabdian masyarakat ini dapat membantu pengenalan produk dan profil usaha UMKM tersebut.

\section{DAFTAR PUSTAKA}

Audry, C. L., Putri, M. R., Hilmi, Z. M. J., \& Firmadani, F. (2020). Edukasi pencegahan Covid-19 melalui media sosial. ABDIPRAJA (Jurnal Pengabdian kepada Masyarakat), 1(1), 130-139. https://doi.org/10.31002/abdipraja.v1i1.3145

Berawi, M. A. (2020). Empowering healthcare, economic, and social resilience during global pandemic Covid-19. International Journal of Technology, 11(3), 436-439. 
https://doi.org/10.14716/ijtech.v11i3.4200

BNPB. (2020). http://inarisk.bnpb.go.id/panduan_singkat_ina.pdf. Diakses 11 September 2020

Caesaron, D., Salma, S. A., Prasetyo, M. D., \& Rifai, M. H. (2021). Edukasi dan Sosialisasi Pencegahan dan Pengendalian COVID-19 melalui Media Poster di Desa Bojongsoang, Kabupaten Bandung. Abdimas: Jurnal Pengabdian Masyarakat Universitas Merdeka Malang, 6(2), 221-229. https://doi.org/10.26905/abdimas.v6i2.5354

Choiriyah, N. A., Devi, I. M. R., Sanjaya, S. A., Dewi, I. C., \& Rahmah, L. (2021). Penyuluhan Pencegahan Penularan COVID-19 di Lingkungan Kantor dan Pembuatan Lemongrass Coolant melalui Live Zoom. Abdimas: Jurnal Pengabdian Masyarakat Universitas Merdeka Malang, 6(1), 18-26. https://doi.org/10.26905/abdimas.v6i1.4865

Irawan, D., Triana, N., Suwarni, L., \& Selviana, S. (2020). Edukasi protokol kesehatan dan strategi pemasaran online melalui program kemitraan masyarakat di era pandemi Covid-19. Jurnal Masyarakat Mandiri, 4(4), 655-662.

http://journal.ummat.ac.id/index.php/jmm/article/view/2636

KMK No. HK.01.07-MENKES-413-2020. Pedoman Pencegahan dan Pengendalian COVID-19. https://covid19.kemkes.go.id/download/KMK_No._HK.01.07-MENKES413-2020_ttg_Pedoman_Pencegahan_dan_Pengendalian_COVID-19.pdf. Diakses 11 September 2020

Kusumaningrum, T. M., Wardoyo, D. T. W., Fazlurrahman, H., Hadi, H. K., \& Kautsar, A. (2021). Pemberdayaan PKK Kelurahan Sukomulyo di Era Pandemi COVID-19 dengan Inovasi Masker Face Shield. Abdimas: Jurnal Pengabdian Masyarakat Universitas Merdeka Malang, 6(1), 43-51. https://doi.org/10.26905/abdimas.v6il.4887

Majid, N. (2020). Sosialisasi peran ibu rumah tangga sebagai pondasi ketahanan bangsa di tengah Covid-19 pada ibu PKK Desa Badak Baru Kabupaten Kutai Kartanegara. Jurnal Pengabdian Masyarakat (JPM-IKP), 3(2), 76-82. http://trilogi.ac.id/journal/ks/index.php/jpmikp/article/view/697

Prayitno, S. A., Pribadi, H. P., \& Ifadah, R. A. (2020). Peran serta dalam melaksanakan protokol pencegahan penyebaran Corona Virus Disease (Covid-19) pada masyarakat. DedikasiMU(Journal of Community Service), 2(3), 504-510. https://doi.org/10.30587/dedikasimu.v2i3.1657

Sampurno, M. B. T., Kusumandyoko, T. C., \& Islam, M. A. (2020). Budaya media sosial, edukasi masyarakat, dan pandemi COVID-19. SALAM: Jurnal Sosial dan Budaya Syar-I, 7(5), 529-542. https://doi.org/10.15408/sjsbs.v7i5.15210

Satria, B. A., Hasanah, N. H., \& Rudiansyah, R. (2020). Penyuluhan adaptasi tatanan kebiasaan baru desa tangguh Covid-19. ANOA, 1(3), 107-122. http://ojs.uho.ac.id/index.php/anoa/article/view/13242

Satuan Tugas Penanganan COVID-19. (2020). https://covid19.go.id/p/berita/indikatorkesehatan-masyarakat-tentukan-penilaian-risiko-penularan-covid-19. Diakses 11 
September 2020

Sufiyanto, S., Yuniarti, S., \& Andrijono, D. (2020). Sosialisasi dan Edukasi Penilaian Mandiri terhadap Risiko Penularan COVID-19 melalui InaRISK Personal. Abdimas: Jurnal Pengabdian Masyarakat Universitas Merdeka Malang, 5(3), 209-219. https://doi.org/10.26905/abdimas.v5i3.5004

Yunus, N. R., \& Rezki, A. (2020). Kebijakan pemberlakuan lock down sebagai antisipasi penyebaran Corona Virus Covid-19. SALAM: Jurnal Sosial \& Budaya Syar-i, 7(3), 227-238. https://doi.org/10.15408/sjsbs.v7i3.15083

WHO. (2020). Pertimbangan penyesuaian langkah-langkah kesehatan masyarakat dan sosial dalam konteks COVID-19. https://www.who.int/docs/defaultsource/searo/indonesia/covid19/who-2019-ncov-adjusting-ph-measures-2020-1-engindonesian.pdf?sfvrsn $=63 d 5 d 4 f$ _2 . Diakses 11 September 2020

Widayati, S., Fahmi, M., Setiyaningsih, L., \& Wibowo, A. (2021). Digital Community Development: Media Pelestarian Kearifan Lokal Wisata Jurang Toleh Kabupaten Malang. Jurnal Nomosleca, 7(1), 29 - 44. doi:10.26905/nomosleca.v7i1.5490.

Zahrotunnimah, Z. (2020). Langkah taktis pemerintah daerah dalam pencegahan penyebaran Virus Corona Covid-19 di Indonesia. SALAM: Jurnal Sosial dan Budaya Syar-i, 7(3), 247-260. https://doi.org/10.15408/sjsbs.v7i3.15103

(C) 2021 by authors. Content on this article is licensed under a Creative Commons Attribution 4.0 International license. (http://creativecommons.org/licenses/by/4.0/). 